\title{
Local Government and Network Governance in the Era of UN Sustainable Development Goals (sDGs): Gyeongsangbukdo Province and Daegu Metropolitan City in South Korea ${ }^{1}$
}

\section{Gobierno local y gobernanza en red en la era de los Objetivos de Desarrollo Sostenible (ODS) de Naciones Unidas: la provincia de Gyeongsangbukdo y la ciudad de Daegu en Corea del Sur}

\author{
DOI: $10.32870 /$ mycp.v9i27.674
}

\begin{abstract}
Resumen
En este estudio se analizan las principales políticas y actividades de Asistencia Oficial para el Desarrollo (AOD) de los gobiernos locales de Corea del Sur, y cómo estos dos gobiernos locales han adoptado el marco de los Objetivos de Desarrollo Sostenible (ODS). Este estudio ha empleado el enfoque de la gobernanza en red respecto al establecimiento de asociaciones entre la autoridad central y los gobiernos locales, y entre los gobiernos locales y otras partes interesadas de la ayuda a nivel local. Los resultados del estudio sugieren que las políticas y actividades de AOD de los gobiernos locales en Corea del Sur son apenas proporcionales al cambio de norma reciente a nivel internacional.
\end{abstract}

Palabras clave: gobierno local, gobernanza en la red, Objetivos de Desarrollo Sostenible, Corea del Sur, AOD.

Artículo recibido el 21 de octubre de 2019 y dictaminado el 25 de mayo 2020.

1. This work was supported by the Ministry of Education of the Republic of Korea and the National Research Foundation of Korea (NRF-2019S1A5C2A04083308).

2. University of Central Lancashire. Preston, Lancashire, PR1 2HE, United Kingdom. ORCID: https:// orcid.org/0000-0003-1395-7672. E-mail: slim4@uclan.ac.uk

3. Keimyung University, Dept. of Spanish and Latin American Studies. 1095, Dalgubeol-daero, Daegu, Korea. ORCID: https://orcid.org/0000-0003-1820-4928. E-mail: sanghjung@gw.kmu.ac.kr 


\section{Introduction}

With the emergence of the Sustainable Development Goals (SDGs) and their associated implementation process, one of the concepts in the international development cooperation community has been the resulting 'multi-layered partnership' between a wider range of players than before (Lim, 2017). During the implementation process of the Millennium Development Goals (MDGs), which were the predecessors to the SDGs, it was officially admitted that multiple actors are equally important in the development cooperation process, and it was necessary to look beyond the traditional intergovernmental mechanisms consisting of aid from donor governments to recipient governments. Accordingly, other actors such as civil society organizations (CSOs) and nongovernmental organizations (NGOS) have become a critical part of development cooperation, while the private sector has been encouraged to participate in international development cooperation activities. During the original discussions establishing the SDGs, local governments were also included as an important part of the process.

The forms of governance in this exercise have also been evolving. While the MDGs were delivered by a centrally controlled system with a group of dominant stakeholders such as donor governments and international organizations, the SDGs operate on a more voluntary basis with greater interdependence between donors and recipients. For example, while MDG monitoring was centralized by the UNDP, SDG monitoring has been decentralized based on the Voluntary National Review mechanism (VNR). More detail about this change is discussed in Section III. At the national level, decentralization has been encouraged as a means of achieving more efficient and effective development cooperation activities between donor local governments and local governments in developing countries.

With this in mind, this research examines recent international norms relating to local governments and the SDGs based on whether recent norm changes in the SDG implementation process have been realized at the local government level in donor countries - SDGs require donor governments also participate in the implementation process-. It looks at whether official development assistance (ODA) policy and practice at the local government level is commensurate with global norm changes. In doing so, this study has employed 'network governance theory', which is discussed in the following section. While this paper aims to provide policy suggestions in the end, it 
attempts to employ theory to allow us to discuss changing dynamics between central and local governments. In the traditional form, international norms and power relations tended to develop from 'governance theory'. However, the SDGs platform can be understood better through network governance theory as it emphasizes local government's roles as well as central government, which requires a new interpretation — such as network governance.

While various policy papers discuss the importance of local governments in achieving SDGs at the state level specific case studies of local governments have not been thoroughly examined. At the same time, only a few academic studies discuss donor local governments' role in distributing ODA to developing countries, and when it comes to the case of South Korea, this becomes even more limited. For instance, only Chang (2016) and Cho, Park, and Jung (2015) have discussed ODA by local governments in South Korea, but their study does not examine any context regarding the SDG implementation and recent norm change. In comparison, Jung, Ahn, and Lim's (2017) research dealt with local governments' ODA policy issues by including the SDG context; however, their research lacks theoretical perspectives in its discussion. In light of this, this study contributes to the scholarly discussion on the role of local governments in the SDG era according to network governance theory, with the specific case analysis of South Korea.

This study has selected Gyeongsangbukdo Province and Daegu Metropolitan City (hereinafter, Daegu City) as subjects of its case study, as both local governments have provided the highest volume of ODA to developing countries, after Seoul, Gyeonggi Province and Incheon Metropolitan City (Export-Import Bank of Korea, 2017). As such, this research has employed a case study methodology to conduct qualitative research. As the nature of the case study as a research method is intended, it does not necessarily mean that the research findings in this study represent all the local government cases in South Korea, which, at the same time, can be considered as a limitation of the study. Nevertheless, it provides an implication that future research needs to be conducted more rigorously within the comparative approach with cases of other local governments in South Korea. However, this will be available only when the rest of local governments in South Korea increase their ODA volume so that the comparison can produce more meaningful results. Currently, the size of ODA from each local government in South Korea, apart from Seoul, Gyeonggi Province, Incheon Metropolitan City and the cases in this study, does not allow us to conduct sensible comparative study due to its relatively small amount of ODA. 
To conduct a triangulation of data analysis, both primary and secondary sources were collected, along with interviews that were adopted from the data set of the research of Jung et al. (2017). As it is qualitative research, we do not intend to include a large number of interviews but are more focused on interviews from six key stakeholders included in Jung et al. (2017).

This research is organized into five sections. After the introduction, the second section reviews and compares theories of governance and network governance. The third section explores recent norm changes in international development cooperation in the context of SDGs by looking at how the traditional development cooperation governance system has evolved into network governance. Based on the theoretical analysis in these two sections, section four analyses two cases of local governments in South Korea: Gyeongsangbukdo Province and Daegu City. Finally, section five provides discussion and concluding remarks on the research.

\section{From governance to network governance}

Governance can be defined as a method of ruling communities. It can be shown in the forms of system, institution, and management methods (Kim, 2005). Governance refers to 'the development of the governing styles in which boundaries between and within public and private sectors have become blurred' (Stoker, 1998 p. 17), and it can be understood as the 'interdependence and continuing interactions between organizations and network members' (Rhodes, 2007 p. 4). However, as seen, the concept of governance has not been clearly understood, and thus, has been somewhat vague in its definition. Nevertheless, the concept of governance began to be used more widely ever since the 1990s, when the international development cooperation community began to consider governance as one of the main factors that can improve aid effectiveness in developing countries. Ever since then, the concept of governance has included factors such as diversity, complexity, and dynamics (Kooiman, 2003; Bae, 2010).

In comparison, network governance can be defined as 'a hybrid form of governance' (Zander, Trang, \& Kolbe, 2016 p. 110), and can be understood in the context of pluralism (Lee \& Yoo, 2016). In other words, network governance is decentralized by social actors, such as local governments, businesses, interest groups, and csos, when the spectrum of power and influence within the concept of governance is more likely to be focused on the central 
government (Hasler, Kubler, Christman \& Marcinkowksi, 2016; Lee \& Yoo, 2016). Accordingly, the concept of power in network governance is defined as social problem-solving capability through cooperation among stakeholders (Lee \& Yoo, 2016). Moreover, network governance can be understood as a horizontal system, while governance is a vertical system. Because of this reason, network governance focuses on interaction, collaboration, relationships, cooperation, connection systems, and management of a connected network of participants (Lee \& Kim, 2014; Zander, Trang \& Kolbe, 2016). Recently, a need for network governance in policy areas has been spotlighted as multiple actors tend to be engaged in the policy-making process (Hasler et al., 2016; Lee, 2014; Zander et al., 2016).

In more detail, we have reviewed the differences between hierarchical governance and network governance by reflecting on Lee and Yoo (2016)'s analysis of power, distribution of resources, characteristics of power, nature of politics, and policy implementation methods, as in Table 1.

Table 1

Comparison of governance and network governance

\begin{tabular}{|c|c|c|}
\hline & Governance & Network Governance \\
\hline $\begin{array}{l}\text { Distribution of } \\
\text { Authority and } \\
\text { Resources }\end{array}$ & Centralized & $\begin{array}{l}\text { Decentralized between central } \\
\text { governments and local governments }\end{array}$ \\
\hline $\begin{array}{l}\text { Characteristics } \\
\text { of Power }\end{array}$ & Controlling other power entities & $\begin{array}{l}\text { Addressing current challenges of the } \\
\text { local governments }\end{array}$ \\
\hline $\begin{array}{l}\text { Characteristics } \\
\text { of Politics }\end{array}$ & Zero-sum relations & Positive sum relations \\
\hline $\begin{array}{l}\text { Policy } \\
\text { Management } \\
\text { Methods }\end{array}$ & $\begin{array}{l}\text { Unilateral order, control, } \\
\text { instructions }\end{array}$ & $\begin{array}{l}\text { Interdependent via compromise, } \\
\text { negotiations, and cooperation }\end{array}$ \\
\hline $\begin{array}{l}\text { Means of Policy } \\
\text { Management }\end{array}$ & $\begin{array}{l}\text { Official legislation and } \\
\text { regulations, along with other } \\
\text { unilateral instructions }\end{array}$ & $\begin{array}{l}\text { Unofficial dialogue and persuasion, } \\
\text { along with other interdependent } \\
\text { methods }\end{array}$ \\
\hline $\begin{array}{l}\text { Methods of } \\
\text { Control }\end{array}$ & $\begin{array}{l}\text { Input and procedure-based } \\
\text { process-oriented control }\end{array}$ & $\begin{array}{l}\text { Output and specific outcome-based } \\
\text { result-oriented control }\end{array}$ \\
\hline Discretion & Order by the central government & $\begin{array}{l}\text { Depending on manager (or local } \\
\text { government) }\end{array}$ \\
\hline
\end{tabular}

Source: Authors' compilation based on Lee and Yoo (2016 pp. 88 and 90). 
As discussed, network governance emphasizes horizontal connectivity between the central government and local government. Its power and resources are decentralized between central and local governments by setting up participants' cooperation as its prerequisite. It is focused on how to address the current challenges of local governments rather than how to rule and control other power entities. When it comes to policy management, interdependent means such as unofficial dialogue and persuasion are emphasized. Unofficial dialogue includes compromise and negotiations. In-network governance, the method of exerting control mainly focuses on outputs and specific results.

According to Fawcett, Manwaring, and Marsh (2011), current policymaking does not solely rely on governance anymore, but rather tends to work through interactions between various actors. In this sense, hierarchical governance has been replaced by horizontal network governance. With this in mind, because traditional relations between the central government and local governments, which were based on hierarchical governance, have recently been changing to forms of horizontal network governance, it is necessary to review recent transformations in the global development cooperation landscape, and how the dynamics of actors have influenced the shape of governance.

\section{SDGs and network governance}

The SDGs, which were endorsed by the member countries during the General Assembly of the United Nations in September 2015, consists of 17 goals with 169 indicators to implement by 2030, while their predecessors, the MDGs, were composed of 8 goals with 21 indicators. The SDGs were designed to overcome the limits of the MDGs and reflect any unfinished business from the period of MDG implementation (2000-2015). While the MDGs were more focused on social development and human development, there was a realization that both economic and social developments are equally important for human development, and thus, the SDGs now balance both developments within those 17 goals. For example, while the MDGs tended to emphasize basic education and health issues, in the SDGs, the goals include infrastructure development for national economic growth (Goals 8 and 9), ensuring clean energy (Goal 7 ), dealing with climate change (Goals 13,14 , and 15), addressing peace and strong institutions (Goal 16), and promoting equalities (Goal 10) (Lim, 2017). The 17 SDG goals and indicators are basically interlinked, covering most of the agenda to be addressed by human beings in the modern era, and deve- 
loped in such a way as to be comprehensive between different goals (United Nations [UN], 2015b).

The emergence of the role of local governments in the SDG implementation process rests on four pillars. First, SDG implementation should be based on a variety of actors and stakeholders. During the MDG implementation process, it was only halfway through its implementation when the international society recognized the important roles played by stakeholders such as CSOs and NGOS. It was officially recognized in 2008 that CSOs and NGOS are important actors in international development cooperation, during the third OECD DAC High-Level Forum on aid effectiveness in Accra, Ghana (Organisation for Economic Co-operation and Development [OCED], 2008). This had the effect that global goals need to be implemented by various actors and stakeholders, including new as well as traditional players. In line with this, in the SDG process, local governments have begun to walk in the spotlight as well as central governments.

Second, as mentioned above, the SDGs have a much wider range of goals to deal with, which are based on the 'no one left behind' principle. In order to reach different groups of people at various levels, the SDGs cannot be implemented by central governments only. Up until recently, it was most central governments, CSOs and NGOs, but now local governments have been included in this format (Lim, 2017). Having said that, the central and local governments in both developing countries and OECD DAC member countries are equally responsible for implementing the SDGs as stakeholders in development.

Third, a higher level of needs for financial mobilization has been required in order to expand the SDGs at local levels as well as to accomplish these ambitious goals. As there are more goals with more to be considered, SDGs require a higher level of finance. While it was said that the MDGs cost billions of dollars, trillions of dollars of investment are needed to achieve the SDGs (Kim, 2015). The Third International Conference on Financing for Development in Addis Ababa, Ethiopia, in 2015, which was an international discussion forum for global goal achievement and finance, set out action points to contribute to successful SDG achievement, including domestic public resources, domestic and international private business and finance, international development cooperation, international trade as an engine for development, debt and debt sustainability, addressing systemic issues, science, and technology, innovation, and capacity building (Addis Ababa Action Agenda, AAAA) (UN, 2015a). 
During the discussion, actors, such as local governments, were addressed in terms of finance mobilization.

Finally, SDG Goal 11 (Sustainable Cities and Communities) directly addresses the role of local governments. SDG Goal 11 itself reveals the importance of urbanization and human settlement at the city level, by focusing on local capacity to achieve each target (UN, 2015b, p. 26). As mentioned, in the 2015 AAAA, multi-stakeholder partnerships, in particular with local authorities, were emphasized. Local governments are important actors as they need to provide appropriate local capacities for inclusive and sustainable development (UN, 2015a). For example, a local government in a donor country can have a twinning program based on its comparative advantage of development with other local governments in developing countries, so that they can exchange mutual benefit in the development process and provide a more tailored experience and technical cooperation at the local level (Jung \& Lim, 2018).

Here, when we discuss the role of local governments in the SDGs, local governments have become an important stakeholder as both donors and recipients (Lim, 2017). In other words, local governments need to receive financial support for SDG implementation from central governments in order to enforce the SDG mandate at the national level, but at the same time, local governments can become efficient donors for other local governments. The MDGs focused on development in developing countries, which led to the misunderstanding that the MDGs were responsible for developing countries but not for OECD DAC donor countries. Based on this rationale, the SDGs seem to be based on a parallel approach between central governance (international and national levels) and a decentralized approach (local governments, csos, and NGOs) (Agencia Mexicana de Cooperación Internacional para el Desarrollo [Amexcid], 2014). At the same time, local governments in donor countries can utilize existing partnerships with partner local governments in developing countries. Based on the existing partnership and cooperation mechanism, donor local governments can provide more effective and efficient development cooperation and ODA to local communities in a more sustainable and accountable manner (United Cities and Local Governments [UCLG], 2015). Like twinning, donor local government-partner local government relations in the activities of developing countries can provide peer-to-peer learning (Jung \& Lim, 2018).

As mentioned in the previous section, we have observed that the traditional role of central governments and the relationship between central governments 
and local governments have shifted. In this context, the era of SDGs has transformed the format of global goal implementation from the top-down style of the MDGs (hierarchical governance) to an equally distributed and decentralized style (network governance) in many ways. In particular, in their implementation monitoring mechanism, the SDGs rely on a voluntary monitoring approach on their progress, which is one of the typical features of network governance. As mentioned in the introduction, while the MDG progress monitoring process was centralized within the UN report system, the SDG implementation monitoring process has been set up based on the VNR mechanism (Lim, 2017). In the VNR process, the localization of targets and indicators of the SDGs is emphasized (Together 2030, 2017). While this can be interpreted and analyzed from various angles, this research will focus on the agenda of the SDG implementation process between central governments and local governments in donor countries. The following section will show whether this is really the case. In other words, by exploring the cases of Gyeongsangbukdo Province and Daegu City in South Korea, this study attempts to examine whether localization and network governance have been embedded at the local level in ODA practice in South Korea, as the theory indicates.

\section{Network governance and sdgs in Gyeongsangbukdo Province and Daegu Metropolitan City in South Korea}

In this section, we analyze two local government authorities that provide ODA to developing countries. Gyeongsangbukdo Province, Gyeongsangnamdo Province, and Daegu City are the three largest local governments in the South-Eastern area of South Korea. While Daegu City is located within Gyeongsangbukdo Province, as a metropolitan city, it has its own dependent authority from the provincial administration. By analyzing these two local government cases, we will look at whether there have been any dynamics between central and local governments regarding the SDGs in South Korea.

Gyeongsangbukdo Province has not developed any specific legal or institutional systems for ODA; however, when it revised the 'Gyeongsangbukdo Province Ordinance for International Exchange Cooperation Promotion' in 2016, it noted that Gyeongsangbukdo Province pursues the value of humankind by development cooperation with developing countries. It also states that the ODA activities of Gyeongsangbukdo Province are part of its 'international exchange cooperation' framework (Ministry of the Interior and Safety 
[MOIS], 2016). In terms of budget management, Gyeongsangbukdo Province has set up the Gyeongsangbukdo Province International Cooperation Fund under the 'Gyeongsangbukdo Province Ordinance for International Cooperation Fund Management'. The Fund is used for international exchange cooperation activities and international cooperation activities by csos and NGOs in Gyeongsangbukdo Province, and also includes the ODA budget (MOIS, 2017). ODA policy coherence between Gyeongsangbukdo Province and the central government seems to be highly limited (Jung et al., 2017; Interview C, Inteview D, \& Inteview E).

Most of the ODA budget in Gyeongsangbukdo Province is provided to share Korea's 'Saemaul Undong' (New Village Movement) experience with developing countries. This has been shown in Table 2, which reflects ODA activities provided by Gyeongsangbukdo Province between 2013 and 2019.

\section{Table 2}

Gyeongsangbukdo Province ODA activities (2013-2019)

\begin{tabular}{l|l|l|l|l}
\hline Year & $\begin{array}{l}\text { Provider } \\
\text { Administration } \\
\text { within Province }\end{array}$ & Activity Title & $\begin{array}{l}\text { Recipient } \\
\text { Country }\end{array}$ & $\begin{array}{l}\text { Budget } \\
\text { (KRW, } \\
\text { million })\end{array}$ \\
\hline 2013 & Gyeongsangbukdo & Training and In-Kind Support & $\begin{array}{l}\text { Multiple } \\
\text { Countries }\end{array}$ & 450 \\
\hline $2014-16$ & Gyeongsangbukdo & $\begin{array}{l}\text { Saemaul Model Village Leader } \\
\text { Training in Korea }\end{array}$ & $\begin{array}{l}\text { Multiple } \\
\text { Countries }\end{array}$ & 1,182 \\
\hline 2014-16 & Gyeongsangbukdo & Saemaul Training in Korea & $\begin{array}{l}\text { Multiple } \\
\text { Countries }\end{array}$ & 515 \\
\hline $2014-16$ & Gyeongsangbukdo & $\begin{array}{l}\text { Saemaul Student Training in } \\
\text { Korea }\end{array}$ & $\begin{array}{l}\text { Multiple } \\
\text { Countries }\end{array}$ & 125 \\
\hline $2014-16$ & Gyeongsangbukdo & Local Saemaul Training & $\begin{array}{l}\text { Multiple } \\
\text { Countries }\end{array}$ & 222 \\
\hline $2014-16$ & Gyeongsangbukdo & $\begin{array}{l}\text { Saemaul Training with Ministry } \\
\text { of the Interior and Safety (MOIS) }\end{array}$ & $\begin{array}{l}\text { Multiple } \\
\text { Countries }\end{array}$ & 48 \\
\hline 2016 & Gyeongsangbukdo & $\begin{array}{l}\text { Saemaul Leader Training in } \\
\text { Korea }\end{array}$ & $\begin{array}{l}\text { Multiple } \\
\text { Countries }\end{array}$ & 171 \\
\hline 2013 & Gyeongsangbukdo & Global Saemaul Pilot Village & $\begin{array}{l}\text { Multiple } \\
\text { Countries }\end{array}$ & 150 \\
\hline $2013-17$ & Gyeongsangbukdo & Global Saemaul Pilot Village & Ethiopia & 2,212 \\
\hline
\end{tabular}


Local Government and Network Governance in the Era of un Sustainable Development Goals (SDGs): Gyeongsangbukdo Province and Daegu Metropolitan City in South Korea

\begin{tabular}{|c|c|c|c|c|}
\hline Year & $\begin{array}{l}\text { Provider } \\
\text { Administration } \\
\text { within Province } \\
\end{array}$ & Activity Title & $\begin{array}{l}\text { Recipient } \\
\text { Country }\end{array}$ & $\begin{array}{l}\text { Budget } \\
\text { (KRW, } \\
\text { million) } \\
\end{array}$ \\
\hline $2013-16$ & Gyeongsangbukdo & Global Saemaul Pilot Village & Rwanda & $\begin{array}{l}450 \\
\text { (MOIs } \\
\text { budget) }\end{array}$ \\
\hline 2013-17 & Gyeongsangbukdo & Global Saemaul Pilot Village & Rwanda & 1,372 \\
\hline $2013-16$ & Gyeongsangbukdo & Global Saemaul Pilot Village & Tanzania & 1,534 \\
\hline $2013-18$ & Gyeongsangbukdo & Global Saemaul Pilot Village & Senegal & 1,204 \\
\hline 2013-19 & Gyeongsangbukdo & Global Saemaul Pilot Village & Philippines & 924 \\
\hline $2015-20$ & Gyeongsangbukdo & Global Saemaul Pilot Village & Indonesia & 474 \\
\hline 2014-19 & Andong-Si & Global Saemaul Pilot Village & Uzbekistan & 450 \\
\hline 2014-19 & Cheongsong-Gun & Global Saemaul Pilot Village & Philippines & 450 \\
\hline 2014-19 & Yecheon-Gun & Global Saemaul Pilot Village & Vietnam & 450 \\
\hline 2014-19 & Yeongcheon-Si & Global Saemaul Pilot Village & Vietnam & 450 \\
\hline 2014-19 & Cheongdo-Gun & Global Saemaul Pilot Village & Vietnam & 450 \\
\hline 2014-19 & Gumi-Si & Global Saemaul Pilot Village & Sri Lanka & 450 \\
\hline 2014-19 & Pohang-Si & Global Saemaul Pilot Village & Sri Lanka & 450 \\
\hline $2015-20$ & Mungyeong-Si & Global Saemaul Pilot Village & Indonesia & 300 \\
\hline 2016-21 & Gimcheon-Si & Global Saemaul Pilot Village & Indonesia & 150 \\
\hline 2016-21 & Yeongju-Si & Global Saemaul Pilot Village & Cambodia & 150 \\
\hline $2016-21$ & Sangju-Si & Global Saemaul Pilot Village & Cambodia & 150 \\
\hline 2016-21 & Gyeongsan-Si & Global Saemaul Pilot Village & Laos & 150 \\
\hline 2016-21 & Yeongdeok-Gun & Global Saemaul Pilot Village & Philippines & 150 \\
\hline $2016-21$ & Chilgok-Gun & Global Saemaul Pilot Village & Ethiopia & 150 \\
\hline $2016-21$ & Uiseong-Gun & Global Saemaul Pilot Village & Vietnam & 150 \\
\hline 2016-21 & Gunwi-Gun & Global Saemaul Pilot Village & Vietnam & 150 \\
\hline 2016-21 & Bongwha-Gun & Global Saemaul Pilot Village & Vietnam & 150 \\
\hline 2016-21 & Uljin-Gun & Global Saemaul Pilot Village & Vietnam & 150 \\
\hline 2016-21 & Seongju-Gun & Global Saemaul Pilot Village & Vietnam & 150 \\
\hline 2011-15 & Gyeongsangbukdo & $\begin{array}{l}\text { UNESCO Global Education } \\
\text { Cooperation Support Project }\end{array}$ & Vietnam & 700 \\
\hline $2014-16$ & Gyeongsangbukdo & $\begin{array}{l}\text { UnDP Nepal Project } \\
\text { (Gyeongsangbukdo Style } \\
\text { Green Energy Model Village } \\
\text { Development) }\end{array}$ & Nepal & 110 \\
\hline $2016-20$ & Gumi-Si & $\begin{array}{l}\text { Saemaul Undong } \\
\text { Internationalisation Project }\end{array}$ & Ethiopia & 1,000 \\
\hline 2014 & Uiseong-Gun & $\begin{array}{l}\text { Mongolia Mandal Sum Saemaul } \\
\text { Hall Construction }\end{array}$ & Mongolia & 30 \\
\hline
\end{tabular}

Source: Authors' compilation based on Jung et al. (2017, pp. 95-97). 
Saemaul Undong has its origins in the 1970s when South Korea had a period of rapid economic development during its national modernization movement. Saemaul Undong is especially focused in rural areas as a balanced approach to both urban and rural development (Jung, 2016, pp. 367 and 368). Gyeongsangbukdo Province set out 'Gyeongsangbukdo Province Ordinance for Establishment and Management of the Saemaul Undong Internationalisation Foundation' and 'Gyeongsangbukdo Province Ordinance for Saemaul Undong Support' so that it can provide Saemaul Undong related ODA projects more systematically (MOIS, 2012, 2013). Under the Saemaul Undong Internationalisation Foundation's role, Gyeongsangbukdo Province established a midand long-term plan for Saemaul Undong Internationalisation and conducted research projects and organized international forums about Saemaul Undong in order to provide a scholarly platform for Saemaul Undong Internationalisation (MOIS, 2012). At the same time, activities such as volunteer dispatch, Saemaul Model Village development, local Saemaul leader training, project monitoring, and evaluation, and private-public cooperation in developing countries have been provided based on the ODA budget (MOIS, 2013).

The reason why Gyeongsangbukdo Province focuses on Saemaul Undong activities is that it is one of the main regions in South Korea which benefited from the Saemaul Undong activities in terms of its successful rural development model. At the same time, the previous President of South Korea who created Saemaul Undong, Park Jung Hee, took this province as his model case when South Korea began Saemaul Undong in the 1970s (Lim \& Lim, 2013). Accordingly, based on its own development experience, Gyeongsangbukdo Province has provided its ODA to developing countries under the Saemaul Undong Internationalisation Project since 2005.

At the operational level, Gyeongsangbukdo Province does not have a specific ODA team or department; however, most of the ODA provided by Gyeongsangbukdo Province is dealt with by the Job Creation and Public Welfare Department and the Administration Autonomy Department. Under the Job Creation and Public Welfare Department, the Global Trade Cooperation Team is in charge of international exchange activities as well as ODA activities. In this team, general data and statistics about ODA activities are dealt with as well. The Administration Autonomy Department, Saemaul Service Team works as a control tower for Saemaul Undong Industrialisation. Because most of ODA activities provided by Gyeongsangbukdo Province are Saemaul Undong related, it can be said that most of the ODA budget in Gyeongsangbukdo Province 
is executed by the Local Autonomy Administration Bureau (GyeongsangukDo, 2019). There has been lack of activities which engaged the local private sector in Gyeongsangbukdo Province's ODA (Jung et al., 2017; Interview A).

Daegu City provides development cooperation as part of its 'international exchange cooperation'. In other words, Daegu City as a local government cooperates with other countries' local governments or international organisations in its ODA activities (Daegu Metropolitan City, 2014). Accordingly, in the revised form of the 'Daegu Metropolitan City Municipal Ordinance for the Global City Promotion', it defines Daegu City's 'international exchange cooperation' as

[...] all kinds of activities and processes which promote cooperation, mutual understanding and friendship by human resources exchange, in-kind resources exchange, and information and knowledge exchange, based on the equal relationship that goes beyond borders between states (MOIs, 2015).

To enhance the City's international exchange cooperation, the municipal ordinance provides a method of twinning between cities. That is, the municipal ordinance encourages the City to set up twinning programmes with other countries' local governments (MOIS, 2015). Twinning can be understood as an effective capacity development method which is based on technical cooperation between donor and recipient local governments in the context of development cooperation (Jung \& Lim, 2018). At the same time, the municipal ordinance shows that the City Mayor supports the full amount or a part of the budget when CsOs and NGOs, international development cooperation organisations, and universities conduct international exchange projects (MOIS, 2015).

However, Daegu City has not set out any specific content about development cooperation and/or the ODA itself in its municipal ordinance. Instead, it is stated in its ODA plan that Daegu City's ODA activities and development cooperation reflect the central government's ODA policy (Lee \& Kim, 2014). According to Korea's 2017 ODA White Paper, the government of South Korea provides three main policy pillars of ODA - integrative ODA, substantive ODA, and collaborative ODA - by reflecting the SDGs in the policy (Committee for International Development Cooperation [CIDC], 2017, p.70). However, it is unclear how specifically Daegu City has abided by the central government's ODA policy. According to the interviewees, ODA policy coherence between 
Daegu City and the central government and the central-local government's interdependent system seem to be barely implemented in practice (Jung et al., 2017; Interview B, Inteview C \& Inteview D).

At the operational level, the International Cooperation Team within the International Cooperation Department at the Daegu City Office used to deal with ODA activities. As of 2019, the Job and Investment Bureau under the International Affairs and Trade Division plays the role of control tower for Daegu City's ODA activities and coordination and statistics management, led by the Vice Mayor for Economic Affairs (Jung et al., 2017; Interview B). At the same time, the municipal ordinance clearly states that the City Mayor can create and manage the 'Daegu Metropolitan City Global Centre to provide systematic and efficient international exchange cooperation activities in the City' (MoIs, 2015). Accordingly, Daegu International Development Cooperation Centre was introduced in January 2015 at Kyungpook National University, as a local level ODA platform (Daegu International Development Cooperation Center [DGIDCC], 2016), and it has been relocated to Keimyung University since 2019. However, it is not clear what its roles and responsibilities are or how the division of labour works between the International Cooperation Team and the Daegu International Development Cooperation Centre.

The ODA amount in Daegu City has increased, and the profile has been also changed from training and technical cooperation to project types. However, resulting from the aforementioned confusion at the operational level and a lack of clear management control, the ODA statistics in Daegu City have not been systematically recorded or published publicly. In accordance with this, Table 3 shows the ODA activities provided by the Daegu Metropolitan City between 2012 and 2017. In this, we have analysed ODA activities based on what we were able to access — research by Jung et al. (2017), which used a data set provided by the Daegu International Cooperation Department. 
Local Government and Network Governance in the Era of un Sustainable Development Goals (SDGs): Gyeongsangbukdo Province and Daegu Metropolitan City in South Korea

Table 3

Daegu Metropolitan City ODA activities (2012-2017)

\begin{tabular}{|c|c|c|c|c|c|c|}
\hline Year & \begin{tabular}{|l|} 
Activity \\
Management \\
Organisation \\
\end{tabular} & Activity Title & Activity Type & Activity Sector & $\begin{array}{l}\text { Budget } \\
\text { Source }\end{array}$ & \begin{tabular}{|l} 
Budget \\
(KRW, \\
million) \\
\end{tabular} \\
\hline $\begin{array}{l}2015- \\
17\end{array}$ & $\begin{array}{l}\text { Keimyung } \\
\text { University }\end{array}$ & $\begin{array}{l}\text { Health } \\
\text { Administration } \\
\text { Capacity } \\
\text { Development }\end{array}$ & $\begin{array}{l}\text { Training in } \\
\text { Korea }\end{array}$ & $\begin{array}{l}\text { Public } \\
\text { Administration }\end{array}$ & $\begin{array}{l}\text { National } \\
\text { and City } \\
\text { Budget } \\
\text { Matching } \\
\text { Fund }\end{array}$ & 150 \\
\hline $\begin{array}{l}2016- \\
18\end{array}$ & $\begin{array}{l}\text { Korea Textile } \\
\text { Development } \\
\text { Institute }\end{array}$ & $\begin{array}{l}\text { Textile Industry } \\
\text { Development } \\
\text { Strategy }\end{array}$ & $\begin{array}{l}\text { Training in } \\
\text { Korea }\end{array}$ & $\begin{array}{l}\text { Industry and } \\
\text { Energy }\end{array}$ & $\begin{array}{l}\text { National } \\
\text { and City } \\
\text { Budget } \\
\text { Matching } \\
\text { Fund }\end{array}$ & 150 \\
\hline 2016 & \begin{tabular}{|l} 
Daegu \\
National \\
University of \\
Education \\
\end{tabular} & $\begin{array}{l}\text { Vietnam } \\
\text { Elementary School } \\
\text { Teacher Capacity } \\
\text { Development } \\
\end{array}$ & $\begin{array}{l}\text { Technical } \\
\text { Cooperation }\end{array}$ & Education & $\begin{array}{l}\text { City } \\
\text { Budget }\end{array}$ & 50 \\
\hline 2015 & $\begin{array}{l}\text { Daegu } \\
\text { Gyeongbuk } \\
\text { International } \\
\text { Exchange } \\
\text { Association } \\
\end{array}$ & $\begin{array}{l}\text { Voluntary Activity } \\
\text { in Laos }\end{array}$ & $\begin{array}{l}\text { Volunteer } \\
\text { Dispatch }\end{array}$ & Health & $\begin{array}{l}\text { City } \\
\text { Budget }\end{array}$ & 10 \\
\hline $\begin{array}{l}2015- \\
16\end{array}$ & $\begin{array}{l}\text { Daegu } \\
\text { Gyeongbuk } \\
\text { International } \\
\text { Exchange } \\
\text { Association } \\
\end{array}$ & $\begin{array}{l}\text { Medical Voluntary } \\
\text { Activity in Almaty }\end{array}$ & $\begin{array}{l}\text { Volunteer } \\
\text { Dispatch }\end{array}$ & Health & $\begin{array}{l}\text { City } \\
\text { Budget }\end{array}$ & 30 \\
\hline 2016 & $\begin{array}{l}\text { Daegu } \\
\text { Gyeongbuk } \\
\text { International } \\
\text { Exchange } \\
\text { Association } \\
\end{array}$ & $\begin{array}{l}\text { Voluntary Activity } \\
\text { in Developing } \\
\text { Countries }\end{array}$ & $\begin{array}{l}\text { Volunteer } \\
\text { Dispatch }\end{array}$ & Health & $\begin{array}{l}\text { City } \\
\text { Budget }\end{array}$ & 10 \\
\hline $\begin{array}{l}2014- \\
15\end{array}$ & Daegu City & $\begin{array}{l}\text { Automatic Official } \\
\text { Document Issue } \\
\text { Machine in Da } \\
\text { Nang, Vietnam }\end{array}$ & Project & $\begin{array}{l}\text { Public } \\
\text { Administration }\end{array}$ & $\begin{array}{l}\text { National } \\
\text { and City } \\
\text { Budget } \\
\text { Matching } \\
\text { Fund }\end{array}$ & 150 \\
\hline 2014 & $\begin{array}{l}\text { Daegu City, } \\
\text { Medicity } \\
\text { Daegu and } \\
\text { Others } \\
\end{array}$ & $\begin{array}{l}\text { Medical Voluntary } \\
\text { Activity in } \\
\text { Kathmandu and } \\
\text { Dhulikhel, Nepal }\end{array}$ & $\begin{array}{l}\text { Volunteer } \\
\text { Dispatch }\end{array}$ & Health & $\begin{array}{l}\text { City } \\
\text { Budget }\end{array}$ & 120 \\
\hline
\end{tabular}


Sojin Lim y Sang-Hee Jung

\begin{tabular}{|c|c|c|c|c|c|c|}
\hline Year & $\begin{array}{l}\text { Activity } \\
\text { Management } \\
\text { Organisation }\end{array}$ & Activity Title & Activity Type & Activity Sector & $\begin{array}{l}\text { Budget } \\
\text { Source }\end{array}$ & $\begin{array}{l}\text { Budget } \\
\text { (KRW, } \\
\text { million) }\end{array}$ \\
\hline 2015 & $\begin{array}{l}\text { Daegu City, } \\
\text { Medicity } \\
\text { Daegu and } \\
\text { Others }\end{array}$ & $\begin{array}{l}\text { Medical Voluntary } \\
\text { Activity in Ho Chi } \\
\text { Minh and Hanoi, } \\
\text { Vietnam }\end{array}$ & $\begin{array}{l}\text { Volunteer } \\
\text { Dispatch }\end{array}$ & Health & $\begin{array}{l}\text { City } \\
\text { Budget }\end{array}$ & 150 \\
\hline 2016 & $\begin{array}{l}\text { Daegu City, } \\
\text { Medicity } \\
\text { Daegu and } \\
\text { Others }\end{array}$ & $\begin{array}{l}\text { Medical Voluntary } \\
\text { Activity in } \\
\text { Karaganda, } \\
\text { Kazahstan }\end{array}$ & $\begin{array}{l}\text { Volunteer } \\
\text { Dispatch }\end{array}$ & Health & $\begin{array}{l}\text { City } \\
\text { Budget }\end{array}$ & 150 \\
\hline 2015 & $\begin{array}{l}\text { Kyungpook } \\
\text { National } \\
\text { University }\end{array}$ & $\begin{array}{l}\text { Human Network } \\
\text { Development } \\
\text { for Agriculture } \\
\text { University Exchange } \\
\text { Students and } \\
\text { Civil Servant } \\
\text { from Developing } \\
\text { Countries }\end{array}$ & $\begin{array}{l}\text { Network } \\
\text { Development }\end{array}$ & $\begin{array}{l}\text { Agriculture } \\
\text { and Fishery }\end{array}$ & $\begin{array}{l}\text { City } \\
\text { Budget }\end{array}$ & 30 \\
\hline $\begin{array}{l}2012- \\
16\end{array}$ & $\begin{array}{l}\text { Yeungnam } \\
\text { University }\end{array}$ & $\begin{array}{l}\text { Saemaul Expert } \\
\text { Training }\end{array}$ & $\begin{array}{l}\text { Training in } \\
\text { Korea }\end{array}$ & Education & $\begin{array}{l}\text { City } \\
\text { Budget }\end{array}$ & 1,700 \\
\hline $\begin{array}{l}2014- \\
15\end{array}$ & $\begin{array}{l}\text { Daegu City } \\
\text { Korea Saemaul } \\
\text { Undong } \\
\text { Centre }\end{array}$ & $\begin{array}{l}\text { Voluntary Activity } \\
\text { in Typhoon Areas in } \\
\text { Philippines }\end{array}$ & $\begin{array}{l}\text { Volunteer } \\
\text { Dispatch }\end{array}$ & $\begin{array}{l}\text { Humanitarian } \\
\text { Assistance }\end{array}$ & $\begin{array}{l}\text { City } \\
\text { Budget }\end{array}$ & 60 \\
\hline $\begin{array}{l}2013- \\
17\end{array}$ & $\begin{array}{l}\text { Daegu City } \\
\text { Korea Saemaul } \\
\text { Undong } \\
\text { Centre }\end{array}$ & $\begin{array}{l}\text { Saemaul Undong } \\
\text { Internationalisation } \\
\text { (Supporting } \\
\text { Cooperative } \\
\text { University in } \\
\text { Thanlyn Library in } \\
\text { Yangon, Myanmar) }\end{array}$ & Project & Education & $\begin{array}{l}\text { City } \\
\text { Budget }\end{array}$ & 170 \\
\hline $\begin{array}{l}2016- \\
18\end{array}$ & $\begin{array}{l}\text { Daegu City } \\
\text { Korea Saemaul } \\
\text { Undong } \\
\text { Centre }\end{array}$ & $\begin{array}{l}\text { Saemaul Undong } \\
\text { Internationalisation } \\
\text { (Saemaul } \\
\text { Model Village } \\
\text { Development in } \\
\text { Cambodia) }\end{array}$ & Project & $\begin{array}{l}\text { Public } \\
\text { Administration }\end{array}$ & $\begin{array}{l}\text { City } \\
\text { Budget }\end{array}$ & 150 \\
\hline 2016 & $\begin{array}{l}\text { Daegu City } \\
\text { Quality Skilled } \\
\text { Technical } \\
\text { Association }\end{array}$ & $\begin{array}{l}\text { International } \\
\text { Vocational } \\
\text { Voluntary Activity }\end{array}$ & $\begin{array}{l}\text { Volunteer } \\
\text { Dispatch }\end{array}$ & Others & $\begin{array}{l}\text { City } \\
\text { Budget }\end{array}$ & 20 \\
\hline
\end{tabular}

Source: Authors' compilation based on Jung et al. (2017, pp. 90 and 91).

As seen above, between 2012 and 2017, Daegu City conducted only three project type ODA activities, while the majority (13 out of 16 activities) consisted of 
short-term training in Korea, voluntary dispatch, and technical cooperation. Six activities were provided in the health sector, which was recorded as the majority, while three activities were provided in the education sector. Two activities were for public administration, and the remaining three activities were provided in the industry and energy sector, the agriculture and fishery sector, and the humanitarian assistance sector. In terms of budget, Saemaul Movement Expert Training was the biggest activity. While the rest of the activities did not exceed 170 million KRW, Saemaul Movement Expert Training itself recorded 1,700 million KRW. The reason why some of the activities had a matching fund format was that the Daegu City budget for ODA activities was not sufficient to fund related activities. However, it was hard to find the nexus between the central government and local governments in terms of SDG policy nationwide. It seems that Daegu City's ODA budget is highly independent of the central government's ODA budget. At the same time, it seems that local NGOs' involvement in Daegu City's ODA activities has been limited as well (Jung et al., 2017; Interview F).

\section{Conclusion}

This article examined two local government cases in South Korea in relation to SDG localization in the context of network governance. As seen above, both Gyeongsangbukdo Province and Daegu City provide ODA within the perspective of international exchange cooperation in general. While Gyeongsangbukdo Province seems to have greater experience of ODA than Daegu City, it has also provided its own unique ODA brand activity under the Saemaul Undong mechanism. However, both local governments have provided their ODA based on their general international exchange cooperation policy, neither communicating with the central government's ODA or SDG policies. In other words, we can conclude that SDG localization has not been realized in South Korea with the cases of Gyeongsangbukdo Province and Daegu City.

Based on network governance theory, both Gyeongsangbukdo Province and Daegu City should have communicated with the central government in terms of 'decentralizing' SDG policy and activities, especially by using the comparative advantage of each local government in South Korea which can address challenges in partner local governments in developing countries when they provide ODA. Rather than using interdependent methods of ODA under the SDG mechanism, both cases showed that they prefer to use dependent 
methods, such as Saemaul Undong, compared to the central government approach. In their ODA policy and/or strategy, neither of the two local governments included clauses from the central government's ODA policy or international norms from the SDG agenda. As mentioned previously, one of the main reasons why local governments' ODA activities can be more effective and efficient towards partner local governments in developing countries is due to the twinning effect. However, in our analysis, it was unclear whether both Gyeongsangbukdo Province and Daegu City have provided their ODA based on peer-to-peer learning mechanisms or comparative advantages. For example, when Gyeongsangbukdo Province provides Saemaul Undong ODA, it is because Saemaul Undong was successful at the local level in South Korea in the 1970s, but it does not guarantee that it would work in the same way in a different environment at the partner's local level, especially in the 2010s. Yet, it is noteworthy that one positive feature was that both cases showed a high level of discretion. In other words, rather than depending on the central government order system, both local governments followed their own ordinances, which imply that network governance can be developed further in South Korea.

As an increasing amount of research suggests the effectiveness and efficiency of network governance and as the global norms suggest that localization of the SDGs is something we need to pursue in development cooperation, the findings of this research show that these two cases of local governments in South Korea are not commensurate with either the theory or the international norms. Therefore, we would like to provide policy implications for local governments in South Korea that interdependency needs to be considered at the forefront of their policies. Both Gyeongsangbukdo Province and Daegu City need to set out their ODA policy by revising existing international exchange cooperation ordinances. By doing so, both local governments need to communicate with the central government and global norms. Both local governments need to analyze not only the SDGs but also their comparative advantage of development so that they can better advise their partner local governments. Based on this analysis both local authorities can take the next step to map out their comparative advantages and each SDG goal. In this way, they can prioritize their own SDG goals to support their partner countries. Here, it would be equally important to analyze the partner local governments' needs.

In terms of the SDGs, most of the goals have direct implications for local governments in development discourse. For instance, without mentioning 
SDG Goal 11 (Sustainable Cities and Communities) which directly states the role of local governments, donor local governments' activities will benefit SDG Goal 1 (No Poverty) at the local level in developing countries, where the central government of the donor country has limited access but where donor local governments have more efficient access to those in need with a better understanding (see UCLG, 2017). At the same time, SDG Goal 2 (Zero Hunger) emphasizes food security and sustainable agriculture development, which are more relevant to the local governments' industry. Especially with our case of Gyeongsangbukdo Province, its own experience and know-how in agricultural industry development can be a good peer technical cooperation for partner local governments in developing countries. In light of this, it is critical to analyze and understand each SDG goal for local governments and make them a focus of their ODA activities.

At the same time, local governments will be required to invite various stakeholders at the local level. The SDGs emphasize the importance of CSOs/ NGOs as well as other actors, and thus this should not be different at the local level. In addition, as mentioned above, under the SDG regime, it is required for the government sector to cooperate with more actors for resource mobilization. Not only through the international finance conference series, but also through the SDG Goal 17 (Partnership for the Goals), engagement with the private sector as well as CSOs/NGOs in the SDGs implementation process has been put forward. However, in our analysis, we have found that both local authority cases in South Korea tend to use their own budget for their own activities and lack the necessary cooperation and synergy effects with other stakeholders in development cooperation for developing country partners. Thus, local governments in South Korea need to develop a strategy on how to mobilize other local partners in their ODA activities.

More communication and interactions need to be systematically established between Gyeongsangbukdo Province and Daegu City as well as the central government and both local governments. They are interconnected geographically, and thus, this physical connectivity can bring a synergy not only in terms of the economy but also in encouraging local private sector and CSO/NGO actors. One solution can be found with the Daegu International Development Cooperation Centre. The Daegu International Development Cooperation Centre is linked to the central ODA government body, the Korea International Cooperation Agency (KOICA), and thus, it can play a mediator 
role between central and local policy and strategy (Jung et al., 2017; Interview B \& Inteview D).

In conclusion, network governance does not seem to be embedded in South Korea's ODA policy and practice, especially within the SDG setting. More systematic cooperation and division of tasks need to be implemented between the central and local government communication systems. However, beyond this, local governments need to enhance their development cooperation capacity so that they can adopt ongoing international norms into their mainstream so that both their communities and partner communities in developing countries can mutually benefit.

\section{References}

Agencia Mexicana de Cooperación Internacional para el Desarrollo (AMEXCID). (2014). First High-Level Meeting of the Global Partnership for Effective Development Co-operation. Mexico City: Ministry of Foreign Affairs of Mexico.

$\mathrm{Bae}, \mathrm{J}$. (2010). 지방정부의 네트워크 거버넌스에 관한 연구: 부산시 하천환 경개선 사업을 중심으로 [A Study of the Network Governance of Local Government: A Focus on A Busan River Protection Movement]. 행정논 총 [Korean Journal of Public Administration], 38(3), 169-193.

Chang, H. (2016). 한국 지방자치단체의 공적개발협력 재고찰. 오토피아

[Reconsidering Official Development Cooperation of the Local Governments in South Korea]. 오토피아 [Oughtopia], 31(2), 133-161.

Cho, H., Park, G., \& Jung, H. (2015). 조현주, 박건우, 정헌주 (2015). 한국 지방정부의 공적개발원조(ODA) 결정요인에 관한 실증 분석: 지방의 국계화 수준을 중심으로 [Determinants of Local Governments' ODA in South Korea: An Analysis based on Local Governments' Internalisation Process]. 지방행정 연구 [Korea Research for Local Administration], 29(1), 261-289.

Committee for International Development Cooperation (CIDC). (2017). 2017 Korea's ODA White Paper. Sejong, Committee for International Development Cooperation (CIDC).

Daegu Metropolitan City. (2014). [대구장기발전종합계획] Daegu Long-term Development Master Plan. 
Daegu International Development Cooperation Center (DGIDCC). (2016). About Daegu International Development Cooperation Centre (DGIDCC). Recovered from https://dgidcc.modoo.at/

Export-Import Bank of Korea. (2017). ODA Stats. Recovered from https:// stats.koreaexim.go.kr/odastats.html

Fawcett, P., Manwaring, R., \& Marsh, D. (2011). Network Governance and the 2020 Summit. Australian Journal of Political Science, 46(4), 651-667. Gyeongsangbuk-Do. (2019). Main Organizations. Recovered from http://www. gb.go.kr/eng/page.jsp?largeCode=government\&mediumCode=organ\&L ANGCODE=English

Hasler, K., Kubler, D., Christman, A., \& Marcinkowksi, F. (2016). OverResponsbilised and Over-Blamed: Elected Actors in Media Reporting on Network Governance. A Comparative Analysis in Eight European Metropolitan Areas. Policy \& Politics, 44(1), 135-152.

Interview A. (2016). Private Sector in Gyeongsangbukdo Province / Interviewers: Jung, Ahn and Lim. [ Inteview extracted from Jung, S, Ahn S., \& Lim, S. (2017). A Study to Promote ODA in Daegu-Gyeonbuk Region. Daegu Metropolitan City: Daegu International Development Cooperation Centre).

Interview B. (2016). Government Sector in Daegu Metropolitan City / Interviewers: Jung, Ahn and Lim. [ Inteview extracted from Jung, S, Ahn S., \& Lim, S. (2017). A Study to Promote ODA in Daegu-Gyeonbuk Region. Daegu Metropolitan City: Daegu International Development Cooperation Centre).

Interview C. (2016). NGO in South Korea / Interviewers: Jung, Ahn and Lim. [ Inteview extracted from Jung, S, Ahn S., \& Lim, S. (2017). A Study to Promote ODA in Daegu-Gyeonbuk Region. Daegu Metropolitan City: Daegu International Development Cooperation Centre).

Interview D. (2017). Aid Agency in South Korea / Interviewers: Jung, Ahn and Lim. [ Inteview extracted from Jung, S, Ahn S., \& Lim, S. (2017). A Study to Promote ODA in Daegu-Gyeonbuk Region. Daegu Metropolitan City: Daegu International Development Cooperation Centre).

Interview E. (2017). Government Sector in Gyeongsangbukdo Province / Interviewers: Jung, Ahn and Lim. [ Inteview extracted from Jung, S, Ahn S., \& Lim, S. (2017). A Study to Promote ODA in Daegu-Gyeonbuk Region. Daegu Metropolitan City: Daegu International Development Cooperation Centre). 
Interview F. (2017). NGO in Daegu Metropolitan City / Interviewers: Jung, Ahn and Lim. [ Inteview extracted from Jung, S, Ahn S., \& Lim, S. (2017). A Study to Promote ODA in Daegu-Gyeonbuk Region. Daegu Metropolitan City: Daegu International Development Cooperation Centre).

Jung, S, Ahn S., \& Lim, S. (2017). A Study to Promote ODA in Daegu-Gyeonbuk Region. Daegu Metropolitan City: Daegu International Development Cooperation Centre. [정상희, 안숙영, 임소진. (2017). 대구경북지역 의 ODA 사업 활성화 방안 연구. 대구광역시, 대구국제개발협력센터.] Jung, S., \& Lim, S. (2018). 개발협력의 트위닝 기법과 EU-페루 간 사례연 구: 한국 지방정부에 대한 시사점 [Twinning Method in Development Cooperation: A Case Study of EU-Peru and its implications for Korean Local Governments]. 유럽 연구 [The Journal of Contemporary European Studies], 36(4), 145-169.

Jung, S. (2016). Korean Rural Development Challenge against External Challenges in International Development. The Journal of Korean Cultural Studies, 64, 363-392.

Kim, J. (2015). Billions to Trillions: Ideas to Actions. Statement by President of the World Bank Group during the Third International Conference on Financing for Development. 13 July 2015, Addis Ababa, Ethiopia.

$\mathrm{Kim}, \mathrm{Y}$. (2005). 지방정부와 시민사회 단체간의 뉴거버넌스 관계 연구[A Study on the Relationship of New Governance between Local Government and Civil Society Organisation]. 지 역사회학 [Korean Regional Sociology], 7(1), 75-103.

Kooiman, J. (2003). Governing as Governance. London: SAGE.

Lee, S., \& Kim, H. (2014). 대구광역시 ODA 사업 추진방안 [Daegu Metropolitan City ODA Strategy]. Seoul: Korea Research Institute for Local Administration.

Lee, S., \& Yoo, J. (2016). 한국의 중앙-지방정부간 관계의 특성: 거버넌스 시각에서[Key Features of Central-Local Government Relations in South Korea: A Governance Perspective]. [국가정책연구] Chung-Ang Public Administration Review, 30(2), 83-108.

Lee, M., Yoon, K. S., Cho, S., \& Won, S. (2014). 중앙-지방간 효과적인 협력체 계 구축방안의 모색: 협력적 네트워크 거버넌스의 관점에서 [Designing the Collaborative Mechanism between Central and Local Governments: The Perspective of Collaborative Network Governance]. 지방정부연구 [The Korean Journal of Local Government Studies], 18(1), 121-146. 
Lim, H., \& Lim, J. (2013). 경상북도 새마을운동 세계화사업의 성과평 가 [A Case Study of the Performance evaluation of Saemaeul Undong Globalisation]. 국가정책 연구[Chung-Ang Public Administration Review], 27(4), 139-165.

Lim, S. (2017). Multi-stakeholders, Multi-layered Partnerships of the Sustainable Development Goals (SDGs). Presentation to the 2017 North-East Asia Development Cooperation Forum. 28-29 September 2017, Moscow, Russia. Ministry of the Interior and Safety (MOIS). (2012). 경상북도 새마을 세계화재단 설립 및 운영 조례 [Gyeongsangbukdo Province Ordinance for Establishment and Management of the Saemaul Undong Internationalisation Foundation]. Sejong, Ministry of the Interior and Safety (MOIS). Recovered from http://www.law.go.kr/ordinInfoP. do? ordinSeq $=890151$ \&gubun $=$ ELIS

Ministry of the Interior and Safety (MOIS). (2013). 경상북도 새마을운동 지원 에 관한 조례[Gyeongsangbukdo Province Ordinance for Saemaul Undong Support]. Sejong, Ministry of the Interior and Safety (MOIS). Recovered from http://www.law.go.kr/ordinInfoP.do?ordinSeq=970983\&gubun=ELIS

Ministry of the Interior and Safety (MOIs). (2015). 대구광역시 글로벌도시 촉 진 조례[Daegu Metropolitan City Municipal Ordinance for the Global City Promotion]. Sejong, Ministry of the Interior and Safety (MOIS). Recovered from http://www.law.go.kr/ordinInfoP.do?ordinSeq=1208969\&gubun=ELIS

Ministry of the Interior and Safety (MOIS). (2016). 경상북도 국제교류협 력 증진에 관한 조례 [Gyeongsangbukdo Province Ordinance for International Exchange Cooperation Promotion]. Sejong, Ministry of the Interior and Safety (MOIS). Recovered from http://www.law.go.kr/ordinInfoP. do?ordinSeq=1250316\&gubun=ELIS

Ministry of the Interior and Safety (MOIS). (2017). 경상북도 국제협력 기금 운용 조례[Gyeongsangbukdo Province Ordinance for International Cooperation Fund Management]. Sejong, Ministry of the Interior and Safety (MOIS). Recovered from http://www.law.go.kr/ordinInfoP. do? ordinSeq=1279651\&gubun=ELIS

Organisation for Economic Co-operation and Development (OECD). (2008). The Paris Declaration on Aid Effectiveness and the Accra Agenda for Action. Paris: OECD.

Rhodes, R. A. W. (2007). Understanding Governance: Ten Years on. Organization Studies, 28(08), 1-22. doi: https://doi.org/10.1177/0170840607076586 
Stoker, G. (1998). Governance as Theory: Five Propositions. International Social Science Journal, 50, 17-28. doi: https://doi.org/10.1111/1468-2451.00106

Together 2030. (2017). Voluntary National Reviews: What Are Countries Prioritizing? A Review of 'Main Messages' from Volunteer Countries Presented for the 2017 Session of the UN High Level Political Forum on Sustainable Development.

United Cities and Local Governments (UCLG). (2015). The Sustainable Development Goals: What Local Governments Need to Know. Barcelona: United Cities and Local Governments.

United Cities and Local Governments (UCLG). (2017). National and SubNational Governments on the Way towards the Localisation of the SDGs. Local and Regional Governments' Report to the 2017 HLPF. Barcelona: United Cities and Local Governments.

United Nations (UN). (2015a). Outcome Document of the Third International Conference on Financing for Development: Addis Ababa Action Agenda. A/ CONF.227/L.1. New York: United Nations.

United Nations (UN). (2015b). Transforming Our World: The 2030 Agenda for Sustainable Development. A/RES/70/1. New York: United Nations.

Zander, S., Trang, S., \& Kolbe, L. M. (2016). Drivers of Network Governance: A Multitheoretic Perspective with Insights from Case Studies in the German Wood Industry. Journal of Cleaner Production, 110(2016), 109-120. 